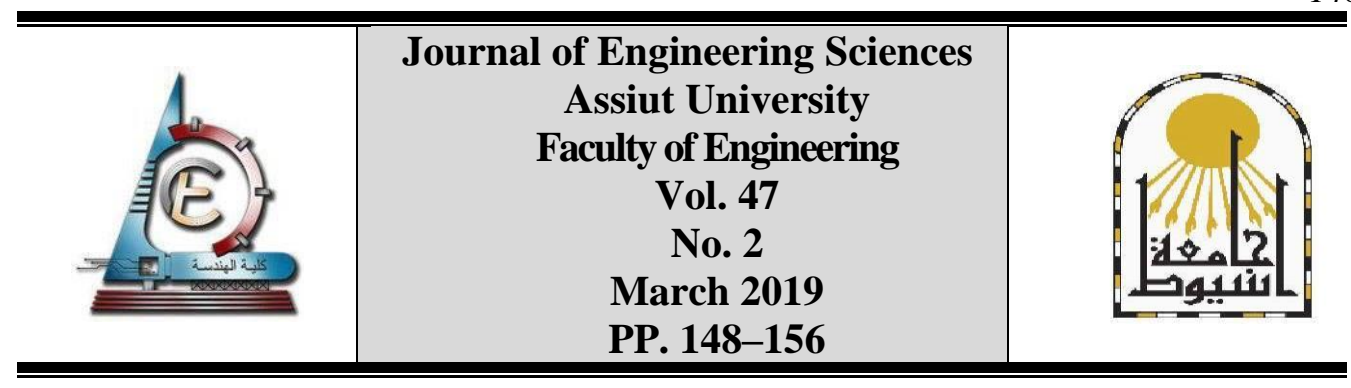

\title{
THE INFLUENCES OF SEMI-SPHERICAL PIN ON FRICTION STIR WELDING FOR DISSIMILAR MATERIAL
}

\author{
Mohamed M.A. Elkhawildi ${ }^{1}$, Ahmed R. S. Essa ${ }^{2}$, \\ Abobker M.O. Helmy ${ }^{3}$, Ramadan I. Elsoeudy ${ }^{4}$ \\ ${ }^{1,3,4}$ Mechanical Eng. Depart, faculty of engineering, Suez Canal University, Egypt \\ ${ }^{2}$ Mechanical Department, faculty of industrial Education, Suez, University, Egypt.
}

Received 1 November 2018; Accepted 18 November 2018

\begin{abstract}
The effects of semi-spherical pin on mechanical properties and microstructure of $7 \mathrm{~mm}$ thick friction stir welded dissimilar aluminum alloys AA7075 and AA5083 were investigated. Threee different pin profiles were used to weld three joints of dissimilar AA7075 and AA5083 Al alloys. Semi-spherical pin, cylindrical pin, and pin with round groove. The friction stir welding was performed at $700 \mathrm{rpm}$ rotational speed and $25 \mathrm{~mm} / \mathrm{min}$ welding speed. Defect-free FSW joint was obtained by using a simple tool with semi-spherical pin. Meanwhile, the crack-like defect is formed in the joints produced by the tools with cylindrical pin, and pin with round groove. The usage of FSW tool with semi-spherical pin (large frictional area of pin) produces a friction stir weld joint with higher tensile strength. When the tool with semi-spherical pin is applied, the grains size was smaller than that when using the other tools.
\end{abstract}

Keywords: Semi-spherical pin, round groove, mechanical properties, frictional area.

\section{Introduction}

Recently, Friction stir welding is one among the foremost solid-state welding processes that have achievements in fastening of the assorted alloys, particularly the dissimilar alloys. Since FSW patented in 1991, the tool geometry has evolved appreciably and the tool profile have become better and better. However, the evolution isn't ended; any enhancements are required during this field [1]. There's a growing demand to enhance the potency of the tool, and fastening high strength alloys, additionally as higher weld joint. The secret is the tool design and also the tool pin profile [2]. The design of FSW tool form ought to be simple as doable to lower the cost value, and also the stirring result ought to be comfortable to good sound welds [3]. The essential a part of the tool pin is to stir the plasticized metal and move the identical behind it to possess higher joint [4]. Thomas et al [5] according that the tool pin profile will unnoticeably influence material flow that was relative to mechanical properties and microstructure evolution of the weld. Elangovan et al [6] and Mao et al [7] according that the pin profile plays an important role in material flow and peak temperature of the nugget zone during FSW. Consequently, it regulates the weld speed of the FSW method. Schmidt et al. [8] and Colegrove et al. [9] exhibited that the tool pin profile had very little 
impact on the heat input. Thomas and St. Nicholas [10] proclaimed that the pin eccentricity is expounded with a dynamic orbit that becomes a component of the FSW method. Recently, analysis fashionable trends involve the result of tool and gear pin eccentricity in friction stir fastening [11-13]. Essa et al. [13] incontestable that the heat generated by the tool with pin eccentricity is bigger than the heat generated by the tool while not pin eccentricity. In spite of those previous achievements, there's no study concerning the result of semi-spherical pin in friction stir welding. Additionally, in order to design effective tools for dissimilar alloys, another new concept is necessary to start, so as to style effective tools for dissimilar alloys, another new conception is critical. However, there's a required to understating the result of pin profile, particularly semi-spherical pin in friction stir welding and also the microstructural changes throughout friction stir welding processes and also the mechanical properties. Since a bigger resistance space should generate a bigger quantity of friction heat [3].Therefore, the aim of this paper is to analyze the result of semi-spherical pin on friction stir welded dissimilar Al alloys AA7075 and AA5083 as another innovative parameter to FSW. AA7075 and AA5083 Al alloys are a precipitation hardened formed materials, AA7075 Al alloy is predicated on $\mathrm{Al}-\mathrm{Zn}$ series, it's one among the strongest $\mathrm{Al}$ alloy employed in several craft structural elements because of its high strength to weight ratio [14, 15]. The $\mathrm{Al}$ alloy 5083 is predicated on $\mathrm{Al}-\mathrm{Mg}$. it is usually used for the applications that needed the nice corrosion resistance [16].

\section{Experimental work}

W302 cold worked alloy steel rod were used to make tools used for welding, and heat treated to $62 \mathrm{HRC}$. Tools with 3 completely various pin shapes are manufactured. One is a semi-spherical pin, the second is a cylindrical pin, and the third tool is pin with spherical groove. In all cases, shoulder of $19 \mathrm{~mm}$ diameter, $2^{\circ}$ concavity, and the pin $6.5 \mathrm{~mm}$ long. The shape of tool pins is shown in figure 1.

The friction stir welded butt joints are cut from rolled plates of AA7075-T651 and AA5083-H111 of $7 \mathrm{~mm}$ thickness. The chemical composition of aluminum alloys AA7075 and AA5083 are listed in Table1. The weld samples are made of two $7 \mathrm{~mm}$ thick, $100 \mathrm{~mm}$ wide, and $120 \mathrm{~mm}$ long plates, and the AA7075 alloy was the retreating side (RS), while, the position of the AA5083 alloy was the advancing side (AS). Measured mechanical properties of used $\mathrm{Al}$ alloys are listed in Table 2. The FSW process for dissimilar $\mathrm{Al}$ alloys AA7075 and AA5083 is performed at weld speed of $25 \mathrm{~mm} / \mathrm{min}, 600 \mathrm{rpm}$ rotational speed, $0.2 \mathrm{~mm}$ tool plunge-depth, and a tilt angle of $3^{\circ}$ is applied.

The samples of metallographic observation were cut perpendicular to the attachment direction. The samples were ground and polished exploitation commonplace metallographic technique, and inscribed by Keller's chemical agent ( $2 \mathrm{ml} \mathrm{HF}, 3 \mathrm{ml} \mathrm{HCL}, 5 \mathrm{ml}$ nitric acid and $190 \mathrm{ml}$ water) for 25 second to appear the microstructures of the weld in many zones.

The hardness test was carried out by Vickers hardness tester; model HV-1000 TMTeck Instrument. The hardness curve of samples were premeditated employing a load of $0.5 \mathrm{kgf}$ with a dwell time of $10 \mathrm{~s}$. Hardness reading values were determined on the middle joints on the cross section perpendicular to the welding direction and also the interval between every indentation was set to two millimetres. Tensile testing is administered on $250 \mathrm{KN}$ capacities "Instron" tensile testing machine. It is used at a rate of $0.0005: 1016 \mathrm{~mm} / / \mathrm{min}$ over a stroke of $1430 \mathrm{~mm}$. Flat tensile samples are cut perpendicular to the welding direction with the size consistent with ASTM, the speed of the moving head of the machine is $0.1 \mathrm{~mm} / \mathrm{s}$. 
The heat which generated during welding process was measured by using Infrared thermometers with laser sighting circle, testo 860-T11. The testo 860-T11 measures a temperature range from -30 to $+900^{\circ} \mathrm{C}$ quickly and while not contact. The new optical device observance defines the world being measured therefore you mostly understand precisely wherever you're measurement.

Table 1.

Chemical ingredients of AA7075 and AA5083

\begin{tabular}{|c|c|c|c|c|c|c|c|c|c|}
\hline Alloys & $\mathrm{Si}$ & $\mathrm{Fe}$ & $\mathrm{Cu}$ & $\mathrm{Mn}$ & $\mathrm{Mg}$ & $\mathrm{Zn}$ & $\mathrm{Ti}$ & $\mathrm{Cr}$ & $\mathrm{Al}$ \\
\hline AA7075 & 0.07 & 0.21 & 1.94 & 0.05 & 2.66 & 5.94 & 0.01 & 0.21 & Bal. \\
\hline AA5083 & 0.04 & 0.15 & 0.02 & 0.56 & 4.75 & 0.04 & 0.05 & 0.05 & Bal. \\
\hline
\end{tabular}

Table 2.

Mechanical properties of AA7075 and AA5083

\begin{tabular}{|c|c|c|c|}
\hline Alloys & $\begin{array}{c}\text { Tensile Strength } \\
(\mathrm{MPa})\end{array}$ & Proof Stress 0.2\% (MPa) & Elongation (\%) \\
\hline AA7075 & 495 & 571 & 11.4 \\
\hline AA5083 & 155 & 307 & 19 \\
\hline
\end{tabular}
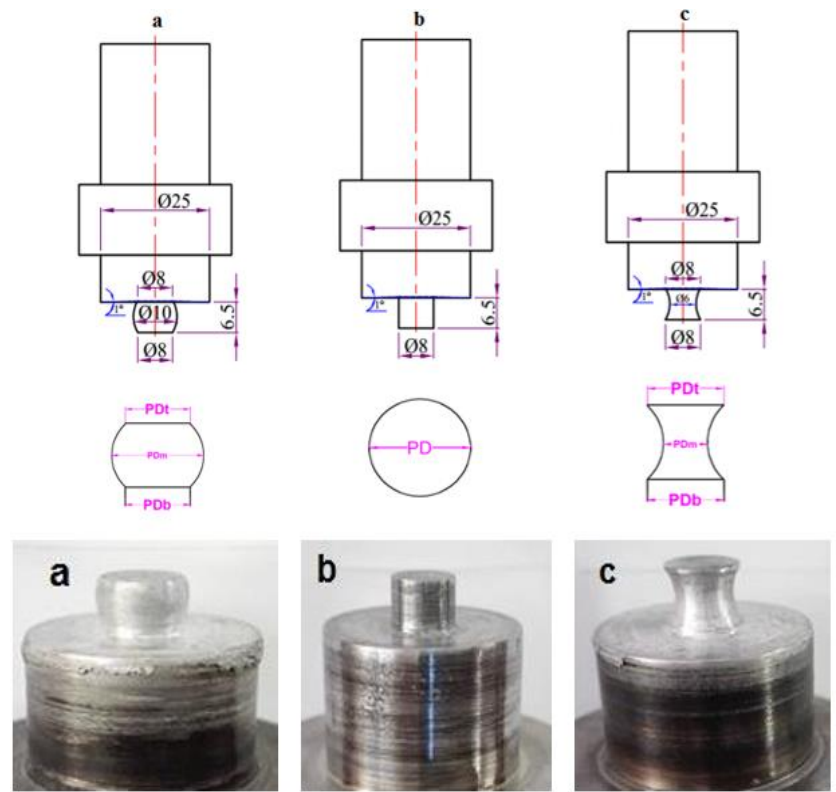

Fig. 1. FSW tool shape. (a) semi-spherical pin, (b) cylindrical pin, (c ) pin with round groove.

\section{Results and discussion}

Figure 2 illustrate the tensile strength of friction stir welded joints of AA7075-AA5083 $\mathrm{Al}$ alloys mistreatment totally different tools. The stress-strain curve of the FSW joints are shown in figure 2, and these results are the average values based on the three tests. The highest tensile strength of the joints was using the tool with semi-spherical pin, which are $299 \mathrm{MPa}$. Obviously this result is because of the welding defects formed in the joints using the other tools, as shown in figure 3. The tensile strength using the tool with cylindrical pin 
is higher than that for the tool with pin with round groove. This result's clearly because of the distributions of fastening defect within the joints shown in figure 3. because the defect become little once victimization the tool with cylindrical pin, the lastingness becomes over the pin with spherical groove, so forming giant defects.

Figure 3 shows the macrostructure of friction stir welded joints of dissimilar AA7075AA5083 Al alloys using different tools semi-spherical pin, cylindrical pin and pin with round groove at a rotational velocity calculable at $700 \mathrm{rpm}$ and travelling velocity is 25 $\mathrm{mm} / \mathrm{min}$. The retreating side is denoted by RS and advancing side is denoted by AS, severally. it's found that, the joint welded by semi-spherical pin is defect-free. However, a crack-like defect is a lot of simply formed in the joint mistreatment the pin with round groove than the usage of the tool with cylindrical pin. For the tool with cylindrical pin, the crack-like defect becomes tiny.

This result explained the fracture morphologies of the tensile samples as illustrated in figure 4 , therefore the variations within the failure options of the tensile samples as well as the place positions of fracture. it's found that the tensile fracture positions of most joints are placed on the AS (AA5083) of the weld, as illustrated in figure 4 (b), (c), associate degreed this can be an shown that the AS is weaker than the RS. However, the joints welded by semi-spherical pin fracture at the BM in figure 4 (a). Mahoney et al [17] rumored that, the deformation is often localized at the weakest interface, then the fracture of the tensile take a look at samples occur thanks to strain localization or residual stress throughout the tensile tests [17]. The interpretation is that it's related to the on top of microstructures a much better stirring impact by the tool with semi-spherical pin will type a superb quality of the weld.

To discuss the inference of semi-spherical pin more, the microstructures within the WNZ centre welded by the three tools are illustrated in figure 5, a definite distinction and alter within the grins size are appear, the grains are smallest and therefore the average size is about $2.8 \mu \mathrm{m}$ welded by tool with semi-spherical pin figure 5(a). However, the size in the joints produced by the other tools with cylindrical pin and pin with round groove are 5, 6.5 $\mu \mathrm{m}$, respectively. This result may be related to the heat which generated by pin surface in this region which arises from the frictional area. When increasing the volume of pin, the tool pin will forging more metals and make more plastic materials flow around the pin, where the material from the front of the tool pin is more forced into the cavity, left by the forward moving pin.

Figure 6 illustrate the assorted zones in FSW joint created by tool with semi-spherical pin at a welding speed of $25 \mathrm{~mm} / \mathrm{min}$ and a rotational speed of 700 r.p.m. Figures five a, $\mathrm{b}, \mathrm{c}, \mathrm{d}$ and e illustrate the weld nugget zone, the thermo mechanical affected zone TMAZ on RS AA7075, TMAZ on AS AA5083, BM of AA7075 and BM of AA5083, severally. The grains in WNZ are fine and equiaxed, may be a typical feature of the dynamically recrystallized structure because of the very best heat generation and highest plastic deformation throughout this region. The TMAZ, a transition zone that situated between the base metal and therefore the weld zone figure $6(\mathrm{~b}, \mathrm{c})$, experiences the joint and interactive influences of moderate resistance heating and plastic deformation, it's defined by a very deformed but not dynamically recrystallized structure due to deficient deformation strain 


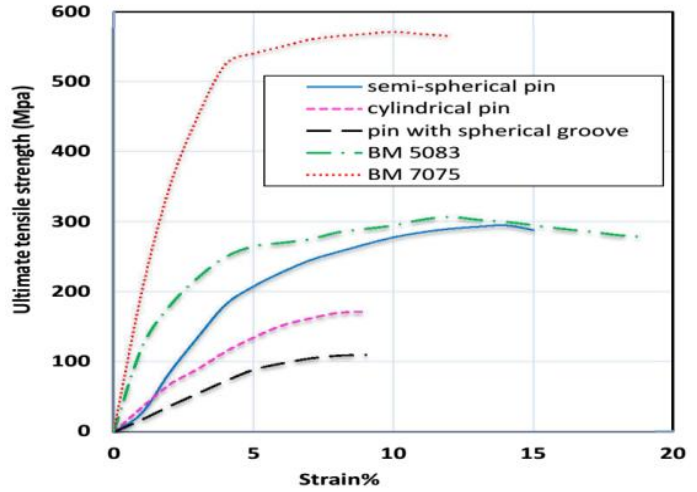

Fig. 2. Tensile strength of dissimilar AA7075 and AA5083 FSW joints at $700 \mathrm{rpm}$ rotational speed, $25 \mathrm{~mm} / \mathrm{min}$ travelling speed.

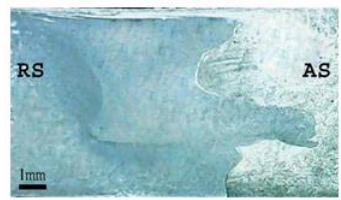

(a)
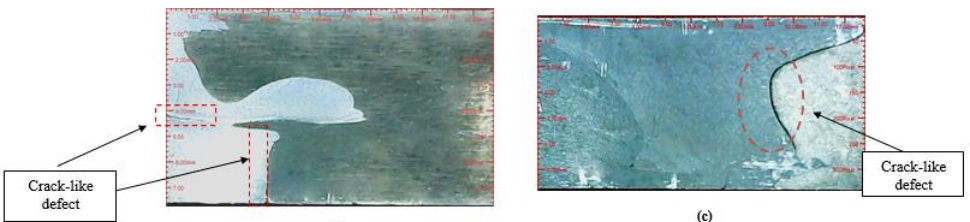

Fig. 3. Macrostructure of AA7075 and AA5083 FSW joints. (a) semi-spherical pin, (b) cylindrical pin, and pin with round groove.

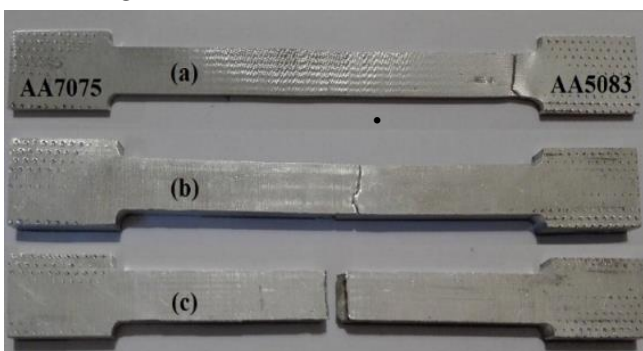

Fig. 4. Tensile fracture position of the joints (a) semi-spherical pin, (b) cylindrical pins, and pin with round groove, respectively.

Figure 7 illustrate the hardness profile through the cross section of the dissimilar AA7075 and AA5083 FSW joints that made by completely different tools semi-spherical pin, cylindrical pin, and pin with spherical groove at 700 rate motility speed and twenty five $\mathrm{mm} / \mathrm{min}$ move speed. The hardness of base material on AA7075 is within the vary of 170-190 HV, and on AA5083 is within the vary of 78-91 HV. it's found that the best hardness is $206 \mathrm{HV}$ on the RS of the weld by the pin with semi-spherical pin. A unexpected decrease happens on the advancing facet (AS) regarding nine metric linear unit removed from the middle of the weld by mistreatment the identical tool. Meanwhile, by mistreatment the opposite tools cylindrical pin and pin with spherical groove, a unexpected drop happens at the advancing facet (AS) regarding half-dozen metric linear unit removed 
from the middle of the weld, one chance may be a amendment within the interface of the WNZ and also the TMAZ that kind partial coarser grains and particles.

There is some reason in which the temperature generated by semi-spherical pin is higher than by the other tools figure 8 , which can cause larger grains and secondary phase particles. Additional reason: better pin pressure and material flow using semi-spherical pin cause finer grains structures and more dispersive distribution of secondary phase particles.
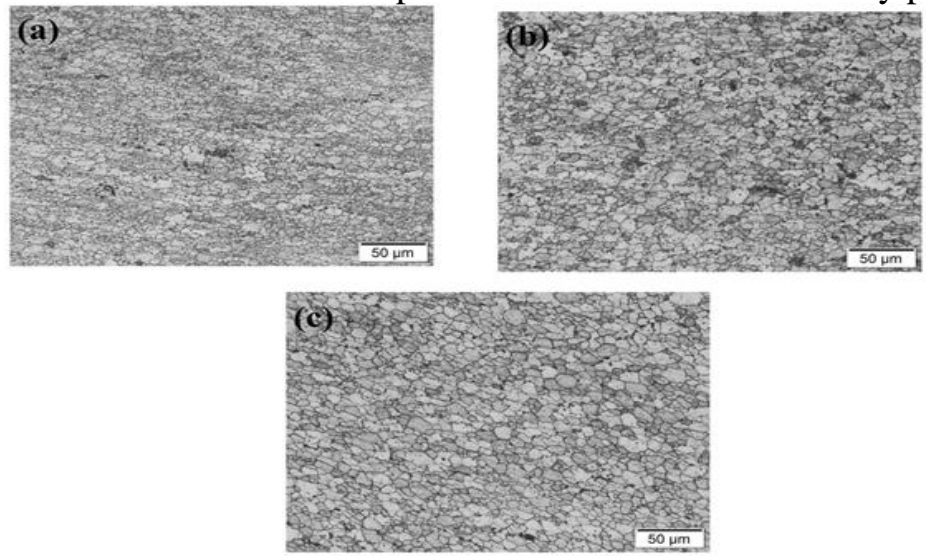

Fig. 5. Microstructures in the WNZ of the joints welded center (a) semi-spherical pin, (b) cylindrical pin, (c) pin with round groove.
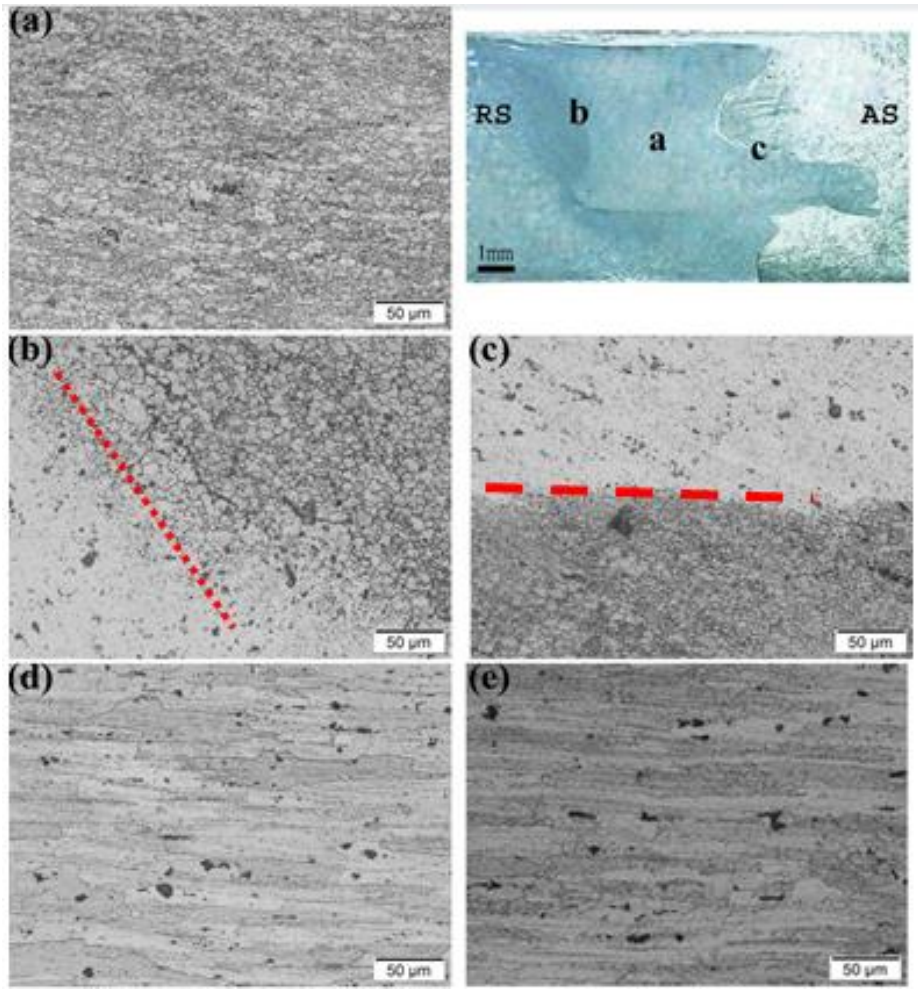

Fig. 6. Optical micrographs across section of the weld joint using semi-spherical pin. (a) WNZ, (b)the interface on the RS AA7075, (c) another interface on the AS AA5083, (d) BM on the AA7075 and (e) BM on the AA5083. 


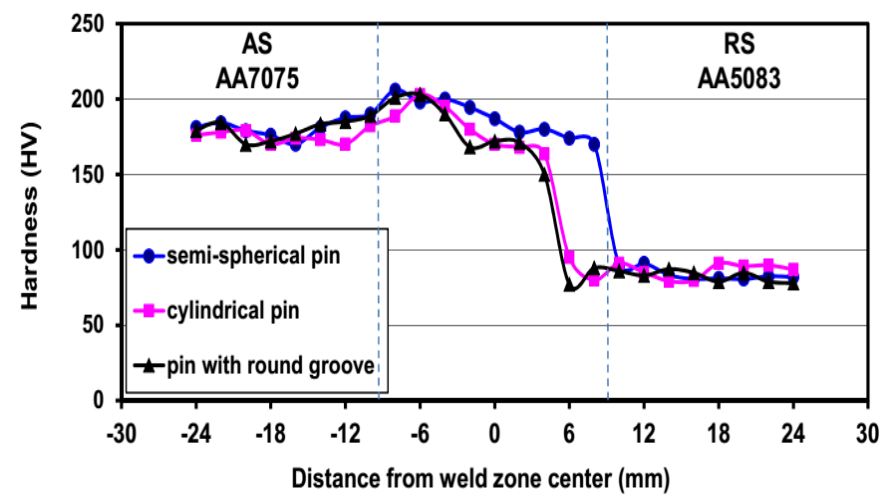

Fig. 7. Hardness profile of dissimilar AA7075 and AA5083 FSW joints at Rs $=700 \mathrm{rpm}$, Ts $=25 \mathrm{~mm} / \mathrm{min}$

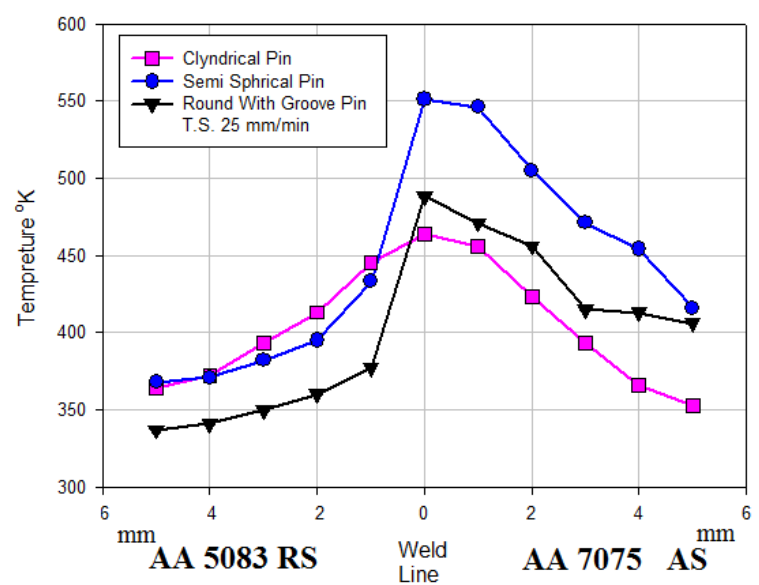

Fig. 8. Temperature distribution on FSW joints dissimilar AA7075-T651 and AA5083-H111 at $\mathrm{Rs}=700$ r.p.m, Ts $=25 \mathrm{~mm} / \mathrm{min}$.

\section{Conclusions}

Based on results, it concluded that:

1. A new FSW pin profile, namely a semi-spherical pin is suggested. However, it needs further study to deeply determine its effects on the friction stir welding process.

2. It is possible to produce defect-free FSW joint with high tensile strength by using a simple tool with semi-spherical pin. The highest strength is achieved at 700 $\mathrm{rpm}$ rotation speed, $25 \mathrm{~mm} / \mathrm{min}$ welding speed. The grains size was the smallest which was about $2.8 \mu \mathrm{m}$.

3. It was found that, the crack-like defect is formed in the joints produced by cylindrical pin tool, and pin with round groove. The smallest defect was formed in the joint welded by the tool with cylindrical pin, and this may be related to the pin pressure and frictional area on pin surface.

4. Suggested tool design may lead to a lower fabrication cost of tool, and better temperature distribution on pin surface during FSW process. 


\section{REFERENCES}

[1] Ahmed, M.M.Z., Ataya, S., Seleman, E.M.M., Ammar, H.R., Essam, A., 2017. Friction stir welding of similar and dissimilar AA7075 and AA5083. Journal of Materials Processing Technology. 242, 77-91.

[2] Meilinger, A., Török, I., 2013. The importance of friction stir welding Tool. Production Processes and Systems. 6, 25-34.

[3] Fujii, H., Cui, L., Maeda, M., and Nogi, K., 2006. Effect of tool shape on mechanical properties and microstructure of friction stir welded aluminum alloys. Material Science and Engineering A. 419, 25-31.

[4] Thomas, W.M., and Dolby, R.E., 2002. Friction stir welding developments. Proceedings of 6th international trends in welding research conference. pp 203-211.

[5] Thomas, W.M, Johnson, K.I, Wiesner, C.S. 2003, Friction stir welding-recent development in tool and process technologies, Adv Eng Mater. 5,485-90.

[6] Elangovan, K., and Balasubramanian, V., 2008. Influences of tool pin profile and tool shoulder diameter on the formation of friction stir processing zone in AA6061 aluminum alloy. Mater Des. 29, 362-373.

[7] Yuqing, M., Liming, K., Fencheng, L., Qiang, L., Chunping, H., and Li, X., 2014. effect of tool pin eccentricity on microstructure and mechanical properties in friction stir welded 7075 aluminum alloy thick plate. Materials and design. 62, 334-343.

[8] Schmidt H, Hattel J, Wert J. 2004, An analytical model for the heat generation in friction stir welding. Model Simul Mater Sci Eng.12,143-57.

[9] Colegrove, P.A., Shercliff, H.R., 2004, Development of Trivex friction stir welding tool Part 2 - three-dimensional flow modelling, Sci. Technol. Weld. Join. 9, 345-351.

[10] Thomas, W.M., and Nicholas, E.D., 1997. Friction stir welding for the transportation industries. Mater Des. 18, 269-273.

[11] Gratecap, F., Girard, M., Marya, S., and Racineux, G., 2011. Exploring material flow in friction stir welding: Tool eccentricity and formation of banded structures. International journal of material forming. 5, 99-107.

[12] Tingey, C., Galloway, A., Toumpis, A., and Cater, S., 2015. Effect of tool centreline deviation on mechanical properties of friction stir welded DH36 steel. Materials and Design. 65, 896-906.

[13] Essa, A.R.S., Ahmed, M.M.Z., Mohamed, A.Y.A., El-Nikhaily, A.E. 2016, An Analytical Model of Heat Generation for Eccentric Cylindrical Pin in Friction Stir Welding. Journal of Materials Research and Technology. 5(3), 234-240.

[14] Feng, A.H, Chen, D.L, Ma, Z.Y., 2010. Microstructure and cyclic deformation behavior of a friction-stir-welded $7075 \mathrm{Al}$ alloy. Metall Mater Trans A. 41, 957-71.

[15] Fuller, C.B, Mahoney, M.W, Calabrese, M, Micona, L., 2010. Evolution of microstructure and mechanical properties in naturally aged 7050 and $7075 \mathrm{Al}$ friction stir welds. Mater Sci Eng A. 527, 2233-40.

[16] Palanivel, R., Mathews, P.K., Murugan, N., Dinaharan, I., 2012. Effect of tool rotational speed and pin profile on microstructure and tensile strength of dissimilar friction stir welded AA5083-H111 and AA6351-T6 aluminum alloys. Materials and Design 40, 7-16.

[17] Mahoney, M.W, Rhodes, C.G, Flintoff J.G, Bingel, W.H, Spurling, R.A.1998, Properties of friction-stir-welded 7075 T651 aluminum. Metall Mater Trans A. 29, 1955-64. 


\section{تاثير البنز الثبه الكروى فى اللحام الاحتكاكى التقليبى للمواد الغير متماثلة}

\section{الملخص العزبى}

تاثير الاداة شبه الكروية على الخو اص الميكانيكية و البنية المجهرية لوصـلات اللحام الاحتكاكى التقليبى

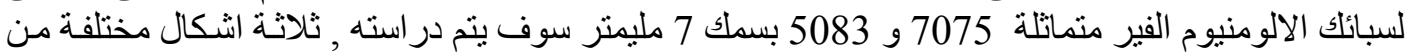

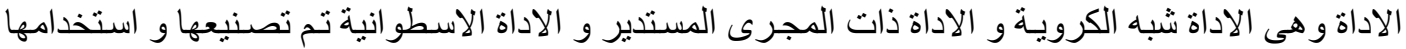

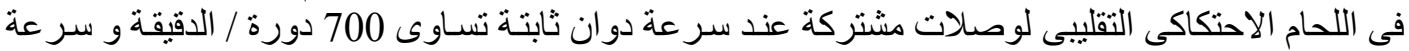

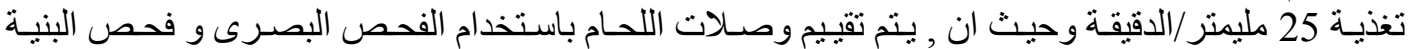
المجهرية بالاضافة الى اختبار الصلابة و الصنافية الصادة وقياس درجة الحرارة المتولدة اثناء عملية اللحام. تم در اسة ثاثثير الثثلاثة ادوات فى الخو اص الميكانيكية و البنية المجهرية و يمكن الحصول على وصلة لحام الحئية

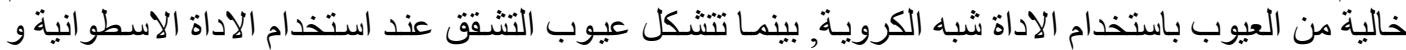

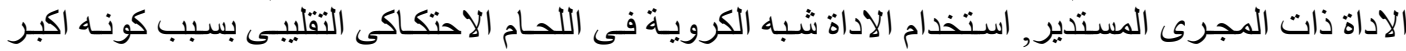

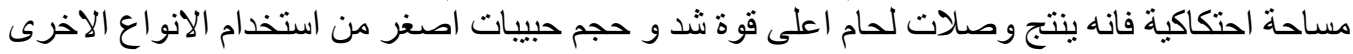

